\title{
Studi Pemanfaatan Dana Desa di Desa Jenggala Kecamatan Tanjung Kabupaten Lombok Utara
}

\author{
Hendra Puji Saputra ${ }^{1}$, Muktasam, Dwi Setiawan Chaniago \\ Universitas Mataram
}

\begin{abstract}
This study discussed the use of village funds before and after the 2018 earthquake in Jenggala Village. The purpose of this study focused on knowing aspects of planning, implementing and evaluating village funds in Jenggala Village, Tanjung Subdistrict, North Lombok Regency. This study uses the structuration theory of Anthony Giddens which explains the concepts of agents and structures, as well as the relationship of structures to agents' social practices. This type of research is qualitative research with a case study approach. Data collection uses interviews, observation, and collecting various documentation. The results showed that during the planning, implementation and evaluation of village funds in Jenggala Village, agents and structures had changed before and after the earthquake. The pattern of utilisation of village funds in Jenggala Village prior to the earthquake was more focused on the field of physical development at 80.76 percent and for the empowerment of village communities it was allocated 19.24 percent. However, after the earthquake the pattern of utilisation of village funds in Jenggala Village experienced a shift and changes in priority programs. The physical development program after the earthquake was only allocated 37.72 percent and focused more on aspects of empowering rural communities which reached 62.28 percent. The lack of community participation, the limited budget of village funds and the delay in the issuance of Regents Regulations after the earthquake have become obstacles in the utilisation of village funds in Jenggala Village.
\end{abstract}

Keywords: Village Funds, Utilisation of Village Funds, Village Development

\begin{abstract}
Abstrak
Penelitian ini membahas tentang pemanfaatan dana desa sebelum dan setelah gempa bumi tahun 2018 di Desa Jenggala. Tujuan dari penelitian ini berfokus untuk mengetahui aspek perencanaan, pelaksanaan, evaluasi dan pemanfaatan dana desa di Desa Jenggala Kecamatan Tanjung Kabupaten Lombok Utara. Penelitian ini menggunakan teori strukturasi Anthony Giddens yang menjelaskan konsep agen dan struktur, serta hubungan struktur dengan praktik sosial agen. Jenis penelitian ini adalah penelitian kualitatif dengan pendekatan studi kasus. Pengumpulan data menggunakan wawancara, observasi, serta mengumpulkan berbagai dokumentasi. Hasil penelitian menunjukkan bahwa pada tahap perencanaan, pelaksanaan dan evaluasi dana desa di Desa Jenggala telah mengalami perubahan agen dan struktur sebelum maupun setelah gempa. Pola pemanfaatan dana desa di Desa Jenggala sebelum terjadinya gempa lebih difokuskan pada bidang pembangunan fisik sebesar 80,76 persen dan untuk pemberdayaan masyarakat desa dialokasikan sebesar 19,24 persen. Namun, setelah gempa bumi pola pemanfaatan dana desa di Desa Jenggala mengalami pergesaran dan perubahan program prioritas. Program pembangunan fisik setelah gempa hanya dialokasikan sebesar 37,72 persen dan lebih difokuskan pada aspek pemberdayaan masyarakat desa yang mencapai 62,28 persen. Minimnya partisipasi masyarakat, terbatasnya
\end{abstract}

\footnotetext{
${ }^{1}$ hendra.sociology@gmail.com
} 
anggaran dana desa serta terlambatnya diterbitkan Peraturan Bupati setelah gempa telah menjadi hambatan dalam pemanfaatan dana desa di Desa Jenggala.

Kata Kunci: Dana Desa, Pemanfaatan Dana Desa, Pembangunan Desa.

\section{Pendahuluan}

Kehadiran Undang-Undang Nomor 6 tahun 2014 tentang Desa telah menempatkan desa sebagai subjek pembangunan agar dapat meningkatkan kesejahteraan masyarakatnya. Desa diberikan kewenangan yang lebih besar untuk mengurus tata pemerintahannya sendiri sehingga diharapkan pemerataan pelaksanaan pembangunan dengan tujuan agar dapat meningkatkan kesejahteraan dan kualitas hidup masyarakat desa dapat berjalan dengan baik. Hal tersebut penting karena permasalahan di desa seperti kesenjangan antar wilayah, kemiskinan, dan masalah sosial budaya lainnya bisa diminimalisir (Petunjuk Pelaksanaan Bimbingan dan Konsultasi Pengelolaan Keuangan Desa Tahun 2015)

Salah satu agenda prioritas pada Periode Pertama Pemerintahan Jokowi yang tertuang dalam NAWACITA adalah upaya membangun Indonesia di mulai dari pinggiran dengan memperkuat daerah dan desa dalam kerangka negara kesatuan (Sandjojo dalam Sri Palupi, dkk, 2016). Pada konteks inilah posisi dan kedudukan desa menjadi sangat penting dan strategis agar dapat mengakomodir segala kepentingan dan kebutuhan masyarakatnya sendiri yang selama ini sering dijadikan objek dalam konsep pembangunan nasional.

Perlakuan dan perhatian khusus terhadap desa pada dasarnya telah merubah paradigma pembangunan nasional yang semula dikenal dengan istilah 'membangun desa' dan kini menjadi 'desa membangun'. Frase desa membangun menunjukkan eksistensi desa baik sebagai objek maupun subjek dalam proses pembangunan (Pengembangan Desa Kementerian Desa, Pembangunan Daerah Tertinggal dan Transmigrasi Republik Indonesia Tahun 2015). Desa kemudian diharapkan menjadi garda terdepan dalam menggapai keberhasilan dari segala urusan dan programprogram pemerintah yang berhubungan langsung dengan desa. 
Kondisi desa yang selama ini kurang menguntungkan dalam konteks pembangunan nasional, kini diarahkan untuk menjadi lebih mandiri. Untuk itu, desa harus diberikan otonomi untuk mengatur dan mengurus kepentingan masyarakatnya sehingga untuk menjalankan kesemuanya itu maka pemerintah desa perlu mendapatkan dukungan dana. Komitmen pemerintah tersebut kemudian terealisasi melalui adanya anggaran dana desa yang mulai dialokasikan sejak tahun 2015.

Berdasarkan data Direktorat Jenderal Perimbangan Keuangan-Kementerian Keuangan Tahun 2015, dana desa dialokasikan sebesar Rp. 20,7 triliun oleh Pemerintah Pusat dengan rata-rata setiap desa mendapatkan sebesar Rp. 280 juta. Pada tahun 2016, dana desa meningkat menjadi Rp. 46,98 triliun dengan rata-rata setiap desa sebesar Rp. 628 juta dan di tahun 2017 kembali mengalami peningkatan menjadi Rp. 60 triliun dengan rata-rata setiap desa sebesar Rp. 800 juta, serta alokasi dana desa pada tahun 2018 tetap sama seperti tahun 2017.

Data Badan Pusat Statistik (BPS) Tahun 2018 menyatakan bahwa terdapat kontribusi dana desa sehingga jumlah desa tertinggal berkurang sebesar 6.518 desa dibandingkan tahun 2014. Kesimpulan atas penurunan jumlah desa tertinggal tersebut didasarkan pada hasil pendataan Potensi Desa (Podes) yang dilakukan oleh BPS dengan menggunakan Indeks Pembangunan Desa (IPD) untuk melihat tingkat perkembangan desa dengan status tertinggal, berkembang, dan mandiri. Hasil dari IPD memperlihatkan bahwa desa tertinggal sebanyak 14.461 desa (19,17 persen), desa berkembang sebanyak 55.369 desa (73,4 persen), dan desa mandiri sebanyak 5.606 desa (7,43 persen).

Provinsi Nusa Tenggara Barat (NTB) merupakan provinsi yang menerima alokasi dana desa setiap tahunnya dari pemerintah pusat untuk mendukung pembangunan daerah. Dalam konteks pengelolaan dana desa, Provinsi NTB adalah satu-satunya provinsi yang ada di Indonesia dengan melakukan program terobosan yang kemudian dikenal dengan istilah Desa Benderang Informasi Publik (DBIP). Hadirnya program tersebut sebagai bentuk imbauan kepada para pemangku kepentingan di level pemerintahan desa agar memberikan transparansi dan akuntabilitas dalam pengelolaan keuangan desa kepada masyarakat desa. 
Kabupaten Lombok Utara merupakan daerah yang mendapatkan peningkatan anggaran dana desa yang pada tahun 2017 dialokasikan sebesar Rp 20 miliar meningkat menjadi Rp 49,8 millir pada tahun 2018. Arah pemanfaatan dana desa diatur melalui Peraturan Bupati Kabupaten Lombok Utara Nomor 1 Tahun 2017 tentang Tata Cara Pembagian dan Penetapan Rincian dana desa bagi setiap desa di Lombok Utara. Peraturan Bupati tersebut diterbitkan mengacu pada aturan yang berada di atasnya untuk dijadikan sebagai salah satu pedoman dalam pemanfaatan dana desa sehingga menghindari terjadinya distorsi dalam tahap implementasinya.

Desa Jenggala Kecamatan Tanjung merupakan desa di Kabupaten Lombok Utara yang mendapatkan alokasi dana desa yang digunakan untuk mempercepat proses pembangunan. Berdasarkan Indeks Desa Membangun (IDM), Desa Jenggala dikategorikan sebagai desa dengan status berkembang. Dalam konteks pemanfaatan dana desa di Desa Jenggala lebih diprioritaskan untuk program pembangunan fisik dan pemberdayaan masyarakat desa.

Pola pemanfaatan dana desa di Desa Jenggala pada perkembangannya mengalami perubahan. Perubahan pemanfaatan dana desa terjadi seiring dengan terjadinya gempa bumi yang dialokasikan untuk rehabilitasi dan rekonstruksi bagi masyarakat korban gempa. Hal tersebut kemudian berdampak terhadap programprogram dana desa yang sudah direncanakan sebelumnya sehingga harus ditunda pelaksanaannya. Secara lebih spesifik, Pemerintah Desa Jenggala dalam praktiknya belum mampu membedakan jenis program setelah gempa terkait pembangunan fisik maupun pemberdayaan sehingga terkesan sangat bias.

\section{Metode Penelitian}

Penelitian yang berlokasi di Desa Jenggala Kecamatan Tanjung Kabupaten Lombok Utara ini menggunakan metode kualitatif dengan pendekatan studi kasus. Penelitian ini bertujuan untuk melihat pemanfaatan dana desa sebelum dan setelah gempa tahun 2018 di Desa Jenggala yang berfokus pada aspek perencanaan, pelaksanaan dan evaluasinya. Selain itu, Pemerintah Desa Jenggala dalam 
praktiknya belum mampu membedakan jenis program setelah gempa terkait pembangunan fisik maupun pemberdayaan sehingga terkesan sangat bias. Adapun pengumpulan data dilakukan melalui wawancara, observasi dan dokumentasi. Analisis data dilakukan dengan reduksi data, penyajian data dan verifikasi/penarikan kesimpulan.

\section{Hasil dan Pembahasan}

\section{Perencanaan Dana Desa di Desa Jenggala Tahun 2018}

\section{a. Perencanaan Dana Desa Sebelum Gempa}

Konsep strukturasi yang dikemukakan Anthony Giddens dapat dipergunakan sebagai acuan dalam melakukan analisis perencanaan dana desa di Desa Jenggala. Konsep tersebut digunakan untuk menjelaskan hubungan antara aktor di level desa yang diposisikan sebagai pelaku (agency) dengan struktur (structure) yang oleh Giddens dikonseptualisasikan sebagai aturan (rules) dan sumber daya (resources). Agen dalam konteks perencanaan dana desa sebelum gempa di Desa Jenggala merujuk kepada pihak-pihak seperti agen formal desa yaitu kepala desa, sekretaris desa, BPD, pendamping desa dan kepala dusun, selain itu juga terdapat agen informal seperti: tokoh masyarakat. Sementara itu, struktur diartikan sebagai regulasi/aturan tentang dana desa dan sumber daya (kemampuan pemerintah desa). Selain itu, masyarakat desa dalam konteks strukturasi disebut sebagai aktor (tindakan individu yang diatur oleh struktur).

Aspek perencanaan merupakan entitas yang tidak bisa dipisahkan

dalam kerangka pembangunan desa melalui dana desa. Dalam konteks perencanaan program dana desa di Desa Jenggala, keterlibatan masyarakat (aktor) di level dusun untuk melaksanakan kegiatan musyawarah dusun atau yang kemudian dikenal dengan istilah musdus menjadi sangat penting. Keterlibatan masyarakat dalam musdus dapat menjadi ruang partisipasi untuk menegosiasikan kepentingan kolektif mereka dalam pembangunan desa melalui struktur yang ada. 
Minimnya partisipasi dan keterlibatan masyarakat di Desa Jenggala dalam mengkuti musdus dikhawatirkan membuat proses perencanaan hanya dilakukan secara sektoral dan bersifat top-down oleh pemerintah desa (agen). Minimnya partisipasi masyarakat dalam musdus tersebut sangat dipengaruhi oleh rasionalitas mereka yang menganggap bahwa usulan-usulan yang disampaikan terkadang tidak dapat diakomodir semuanya ketika dibahas di tingkat musyawarah desa. Belum bisa terakomodirnya semua usulan dari masyarakat disebabkan karena penetapan program ditentukan berdasarkan skala prioritas dan menyesuaikan dengan kapasitas anggaran dana desa mengingat luasnya wilayah di Desa Jenggala.

Wacana program perencanaan pembangunan desa dalam perspektif strukturasi disebut sebagai struktur gugus signifikansi akan disepakati bersama berdasarkan skala prioritas dan kebutuhan riil masyarakat desa. Agen-agen di level pemerintah desa dalam melakukan musyawarah desa memiliki 'kontrol' atau 'kuasa' dalam penetapan program dana desa yang sudah direncanakan untuk dilaksanakan sebagai kebijakannya (struktur gugus dominasi). Adanya pembenaran atas tindakan agen di level desa dalam membuat kesepakatan program perencanaan pembangunan desa tersebut kemudian dituangkan dalam Rencana Kerja Pembangunan Desa (RKPDes) sebagai struktur gugus legitimasi.

Wacana program perencanaan dana desa tahun 2018 (struktur gugus signifikansi) di Desa Jenggala yang disepakati oleh agen-agen di level pemerintahan desa melalui musyawarah desa meliputi perencanaan di bidang pembangunan fisik dan pemberdayaan masyarakat desa yang direncanakan melalui tiga tahap. Setiap tahapan perencanaan program dana desa tersebut merupakan hasil dari musyawarah desa yang dimana telah disepakati secara kolektif dalam APBDes tahun 2018.

Tahap pertama, program dana desa di Desa Jenggala tahun 2018 untuk bidang pembangunan fisik difokuskan pada: Pembangunan, pemanfaatan dan pemeliharaan infrasruktur dan lingkungan desa. Tahap 
kedua dan Tahap ketiga, difokuskan pada: Pembangunan, pemanfaatan dan pemeliharaan infrasruktur dan lingkungan desa; Pembangunan, pemanfaatan dan pemeliharaan sarana dan prasarana kesehatan. Sementara itu, perencanaan program untuk bidang pemberdayaan masyarakat desa melalui dana desa tahun 2018 di Desa Jenggala setiap tahapannya difokuskan pada program: pemberian insentif kepada guru dan kader, penyuluhan bagi masyarakat desa, bantuan stimulan untuk kelompok wisata, kegiatan sosial dan pengadaan sarana prasarana posyandu, serta pemberian permodalan BUMDES.

Meskipun melalui kebijakan dana desa telah membuka dan memberikan ruang partisipasi bagi masyarakat desa untuk menggali potensi dan mengidentifikasi permasalahan yang ada, namun dalam konteks pemanfaatan dana desa di Desa Jenggala belum mampu menumbuhkan kesadaran masyarakat secara maksimal untuk terlibat secara partisipatif dalam perencanaan. Padahal idealnya pembangunan desa yang baik tentu membutuhkan peranan masyarakat sebagai salah satu aktor utamanya. Oleh karena itu, perencanaan program dana desa yang tidak diikuti secara partisipatif oleh masyarakat desa dapat berpotensi menimbulkan program yang tidak sesuai dengan kebutuhan riil masyarakat.

\section{b. Perencanaan Dana Desa Setelah Gempa}

Agen dalam perencanaan dana desa setelah gempa merujuk kepada pihak-pihak yang terlibat dalam tahap perencanaan kembali melalui APBDesPerubahan di Desa Jenggala seperti agen mikro desa yaitu Pemerintah Desa Jenggala beserta semua kepala dusun. Sedangkan agen makro desa yaitu Bupati dengan mengeluarkan Peraturan Bupati Nomor 40 Tahun 2018 tentang Prioritas Dana Desa untuk Rehabilitasi dan Rekonstruksi masyarakat terdampak gempa.

Dalam konteks strukturasi, pemanfaatan dana desa dilakukan oleh agen mikro desa yang memiliki kuasa atau otoritas dalam mengimplementasikan dana desa. Selain itu, agen makro desa memiliki otoritas dalam mengeluarkan aturan berupa Peraturan Bupati untuk 
melegitimasi tindakan yang dilakukan agen mikro desa. Sedangkan masyarakat dalam perspektif strukturasi disebut sebagai aktor yang menjadi subjek program dana desa.

Berkenaan dengan itu, pasca gempa bumi yang terjadi di Lombok telah membawa dampak perubahan terhadap struktur yang ada. Terjadinya gempa bumi pada gilirannya mengharuskan agen untuk melakukan reproduksi struktur yang baru melalui proses perencanaan kembali program dana desa di Desa Jenggala sesuai dengan situasi dan kondisi masyarakat setelah gempa. Struktur yang baru membuka peluang bagi tindakan agen sehingga memungkinkan terjadinya pergeseran program dana desa dari yang sudah direncanakan sebelumnya.

Bahkan lebih jauh itu, dapat dinyatakan bahwa dalam proses terjadinya reproduksi struktur, gugus struktur signifikansi mengalami perubahan dimana wacana program perencanaan dana desa untuk bidang pembangunan fisik dialihkan dengan wacana program perencanaan dana desa untuk proses rekonstruksi dan rehabilitasi masyarakat setelah gempa (gugus struktur signifikansi). Proses perencanaan program dana desa setelah gempa tidak dilakukan melalui mekanisme musdus, melainkan dilakukan melalui APBDes-Perubahan oleh para agen di level desa sebagai pemegang kontrol atas kebijakan yang ada (gugus struktur dominasi), dan kemudian perubahan fokus prioritas perencanaan dana desa setelah gempa didasarkan pada Perbub Nomor 40 Tahun 2018 tentang Penggunaan Dana Desa untuk Rehabilitasi dan Rekonstruksi setelah gempa (gugus struktur legitimasi).

APBDes-perubahan pada dasarnya merupakan representasi dari upaya untuk merespon atas kondisi yang bersifat urgen di masyarakat, termasuk peristiwa bencana gempa bumi. Untuk itu, agen di level Pemerintah Desa Jenggala menyelenggarakan musyawarah perencanaan pembangunan desa yang diadakan secara khusus untuk kepentingan pembahasan dan penyepakatan perubahan RKP Desa yang kemudian menjadi dasar dalam penyusunan perubahan APBDes. Penyelenggaraan musyawarah perencanaan 
pembangunan desa tersebut disesuaikan dengan terjadinya peristiwa khusus atau terjadinya perubahan mendasar.

Salah satu manifestasi dari adanya perubahan APBDes tersebut adalah terjadinya pergeseran program dana desa setelah gempa bumi terhadap program yang sudah direncanakan sebelumnya, khususnya program di pembangunan fisik pada tahap II dan III dialihkan untuk proses rehabilitasi dan rekonstruksi setelah gempa bumi. Adanya pergeseran fokus prioritas tersebut sebagai upaya untuk mempercepat proses pemulihan kondisi masyarakat yang terdampak gempa bumi. Dalam konteks strukturasi, agen di level Pemerintah Desa Jenggala melakukan reproduksi struktur (perubahan RKPDes) sehingga pemanfaatan dana desa dapat bersifat adaptif terhadap kondisi riil di masyarakat. Namun, di satu sisi struktur (Peraturan Bupati Nomor 40 Tahun 2018 tentang Prioritas Dana Desa untuk Rehabilitasi dan Rekonstruksi Pasca Gempa) dapat mempengaruhi dan membentuk tindakan agen mikro desa ketika dalam melakukan proses perencanaan kembali program dana desa setelah gempa bumi.

\section{Pelaksanaan dan Evaluasi Dana Desa di Desa Jenggala Tahun 2018}

\section{a. Pelaksanaan Dana Desa Sebelum Gempa Bumi}

Agen dalam konteks pelaksanaan dana desa sebelum gempa bumi merujuk kepada pihak-pihak yang terlibat dalam melaksanakan program dana desa di Desa Jenggala seperti agen formal desa yaitu Pemerintah Desa Jenggala melalui Tim Pelaksana Kegiatan (TPK) dan unsur masyarakat dalam perspektif strukturasi disebut sebagai aktor. Agen lainnya seperti: BPD berperan dalam mengawasi dan memonitoring setiap tahapan pelaksanaan dana desa.

Agen di level Pemerintah desa Jenggala dalam melaksanakan segala program pembangunan desa mengacu pada wacana perencanaan program dana desa (gugus struktur signifikansi) untuk kemudian diimplementasikan. Wacana perencanaan program pembangunan desa tersebut dalam tataran pelaksanaannya dilakukan secara bertahap dan sistematis sesuai dengan daftar urut kegiatan yang sudah direncanakan. Wacana perencanaan program dana 
desa di Desa Jenggala secara lebih spesifik berfokus pada pembangunan fisik dan pemberdayaan masyarakat desa.

Praktik sosial agen terhadap wacana pelaksanaan program dana desa (gugus struktur signifikansi) dimulai dari bidang pembangunan fisik pada tahap I yang difokuskan untuk: Pembangunan, pemanfaatan dan pemeliharaan infrasruktur dan lingkungan desa seperti: Pembangunan Talud Pemukiman Dusun Kroya; Penataan Gang RT di Kr. Bajo Dusun Tasola; Pembangunan Balai Rakyat Desa Jenggala; dan Pembangunan Ralling Jembatan Dusun Kapu. Sementara itu, wacana pelaksanaan program dana desa (struktur gugus signifikansi) untuk bidang pemberdayaan masyarakat lebih difokuskan pada jenis program seperti: Pemberian Intensif; Penyuluhan bagi masyarakat desa; Pemberian bantuan kepada kelompok wisata; dan Pengadaan sarana dan prasarana kesehatan.

Selanjutnya, wacana pelaksanaan program dana desa (gugus struktur signifikansi) untuk bidang pembangunan fisik pada tahap II masih difokuskan untuk: Pembangunan, pemanfaatan dan pemeliharaan infrasruktur dan lingkungan desa; serta untuk sarana dan prasarana kesehatan. Pelaksanaan program dana desa di Desa Jenggala pada tahap II ini mengalami perubahan dengan apa yang sudah direncanakan sebelumnya. Perubahan tersebut terlihat dari adanya sebagian program yang sudah direncanakan, namun dalam tatanan pelaksanaannya tidak dapat dilaksanakan (take off) sebagai dampak dari adanya gempa bumi. Sementara itu, wacana pelaksanaan program pemberdayaan masyarakat pada tahap II tidak mengalami perubahan setelah gempa. Dengan kata lain, pelaksanaan program pemberdayaan masyarakat sesuai dengan apa yang sudah direncanakan yang difokuskan untuk: Pemberian intensif kader desa dan Pengalokasian modal untuk BUMDES.

\section{b. Pelaksanaan Dana Desa Setelah Gempa Bumi}

Agen dalam pelaksanaan dana desa setelah gempa merujuk kepada pihak-pihak yang terlibat dalam melaksanakan program dana desa di Desa Jenggala seperti agen formal desa yaitu Pemerintah Desa Jenggala melalui 
Tim Pelaksana Kegiatan (TPK) dan unsur masyarakat dalam konsep strukturasi sebagai aktor. Agen lainnya yang terlibat setelah gempa untuk mempercepat rehabilitasi dan rekonstruksi yaitu NGO dalam skala lokal, nasional maupun internasional. Sementara itu, struktur (aturan/regulasi) dalam pelaksanaan dana desa setelah gempa bumi diatur melalui Peraturan Bupati Nomor 40 Tahun 2018 tentang prioritas dana desa untuk rehabilitasi dan rekonstruksi masyarakat terdampak gempa.

Setelah terjadinya gempa bumi telah berdampak terhadap wacana pelaksanaan program dana desa (gugus struktur signifikansi) untuk bidang pembangunan fisik pada tahap III. Semua program di bidang pembangunan fisik pada tahap III yang sudah direncanakan dihentikan pelaksanaannya karena dialihkan untuk pelaksanaan program rehabilitasi dan rekonstruksi masyarakat setelah gempa bumi. Signifikansi dari jenis program tersebut berupa: Penyediaan Sarana dan Prasarana Air Bersih; Pembuatan Sekolah darurat PAUD; Penataan Lingkungan Dusun Langgar Sari (urugan tanah); dan Pembuatan Shelter Pengungsian. Sementara untuk wacana program pemberdayaan masyarakat pada tahap III dalam pelaksanaannya sesuai perencanaan awal, dan terdapat penambahan program untuk merespons peristiwa gempa bumi seperti: Bantuan Stimulan untuk Hunian Sementara (Huntara); Pembersihan Puing Setelah Gempa; Normalisasi Saluran Irigasi Dusun Penyambuan; dan Pengadaan Mesin Penyedot Air Dusun Tanak Song Daya.

Keterlibatan unsur masyarakat dalam pelaksanaan dana desa di Desa Jenggala masih hanya sebatas dengan pola padat karya. Akan tetapi, menumbuhkan kesadaran masyarakat untuk terlibat dalam pelaksanaan dana desa di Desa Jenggala secara swadaya dan gotong-royong masih terkesan cukup minim. Masyarakat di Desa Jenggala masih bersikap apatis terhadap pelaksanaan dan pengawasan program dana desa. Idealnya, adanya partisipasi dan keterlibatan masyarakat secara proaktif dapat mengindikasikan bahwa posisi dan peran masyarakat desa menjadi sangat penting. Artinya, masyarakat desa bukan diposisikan hanya sebatas objek pembangunan, 
melainkan juga sebagai subjek dalam pembangunan desa. Keterlibatan masyarakat tersebut tentu pada gilirannya dapat menjadi daya dukung yang senantiasa menentukan keberhasilan pemanfaatan dana desa dalam pembangunan desa.

Harus diakui bahwa minimnya partisipasi masyarakat dalam pelaksanaan dan pengawasan program dana desa secara swadaya di Desa Jenggala telah menjadi tantangan sekaligus hambatan bagi agen di level pemerintah desa. Kurangnya keterlibatan masyarakat secara swadaya di Desa Jenggala dalam pelaksanaan program dana desa mengindikasikan bahwa kurangnya pemahaman masyarakat tentang arti penting peran dan posisi mereka dalam pembangunan desa. Secara normatif, masyarakat akan merasa dihargai ketika diberikan kesempatan untuk terlibat secara proaktif dalam pembangunan desa. Apalagi program dana desa yang dilaksanakan tersebut secara eksplisit dapat menyentuh langsung persoalan kebutuhan mereka. Sehingga dalam kondisi tersebut, masyarakat akan merasa memiliki terhadap program-program pembangunan desa.

Meskipun demikian, otoritas dan wewenang pelaksanaan pemanfaatan dana desa di Desa Jenggala dikontrol dan dikendalikan oleh agen-agen di level Pemerintah Desa Jenggala. Agen di level desa yang memiliki kontrol dan kendali tersebut dalam konteks strukturasi disebut sebagai gugus struktur dominasi. Adanya kontrol dan kuasa yang dimiliki oleh agen di level Pemerintah Desa Jenggala direpresentasikan dari proses penetapan program dana desa yang harus dilakukan oleh agen di level pemerintah desa. Selain itu, dominasi agen di level pemerintah desa juga terlihat dari proses koordinasi yang dibangun oleh agen kepada masyarakat yang dilibatkan dalam tahap pelaksanaan program dana desa.

Tindakan agen dalam pemanfaatan dana desa didasarkan pada legitimasi yang dimiliki melalui peraturan-peraturan tentang dana desa. Tindakan agen tersebut dilegitimasi melalui Undang-Undang Nomor 6 Tahun 2014 tentang Desa, Peraturan Pemerintah Nomor 60 Tahun 2014 tentang 
Dana Desa yang bersumber dari APBN, Permendagri Nomor 114 Tahun 2014 tentang Pedoman Pembangunan Desa, dan Peraturan Bupati Kabupaten Lombok Utara Nomor 2 Tahun 2017 tentang Prioritas Penggunaan Dana Desa Sebelum Gempa Bumi.

Namun, setelah terjadinya gempa bumi, tindakan agen kemudian dipengaruhi oleh Peraturan Bupati Kabupaten Lombok Utara Nomor 40 Tahun 2018 tentang Prioritas Penggunaan Dana Desa untuk Rehabilitasi dan Rekonstruksi Setelah Gempa Bumi yang notabenenya merupakan produk hukum yang menjadi legitimasi atas pembenaran tindakan agen. Terbitnya Peraturan Bupati Kabupaten Lombok Utara Nomor 40 Tahun 2018 tentang Prioritas Penggunaan Dana Desa untuk Rehabilitasi dan Rekonstruksi Setelah Gempa Bumi tentu mengacu pada aturan yang berada di atasnya.

\section{c. Evaluasi Dana Desa Sebelum Gempa Bumi}

Berdasarkan hasil penelitian, minimnya keterlibatan masyarakat secara swadaya dan gotong-royong dalam pelaksanaan dana desa di Desa Jenggala merupakan aspek penting sebagai bagian dari proses evaluasi. Masyarakat di Desa Jenggala terkesan bersifat apatis untuk terlibat secara swadaya dalam pelaksanaan dana desa. Padahal dengan mengutamakan pemanfaatan sumberdaya manusia, serta mendayagunakan swadaya dan gotong-royong masyarakat melalui mekanisme secara swakelola akan jauh lebih efektif terhadap pembangunan desa. Selain itu, aspek evaluasi penting lainnya dalam pemanfaatan dana desa di Desa Jenggala adalah luasnya wilayah dan padatnya jumlah penduduk dengan anggaran dana desa yang cukup terbatas.

\section{d. Evaluasi Dana Desa Setelah Gempa Bumi}

Evaluasi program setelah gempa bumi dilakukan oleh agen pemerintah desa melalui BPD dengan melakukan pengawasan terhadap struktur (wacana program rehab dan rekon) yang sudah direncanakan melalui APBDes-Perubahan. BPD melakukan pengawasan untuk melihat sejauhmana dinamika dalam pemanfaatan dana desa untuk menghindari ketidaksesuaian antara yang direncanakan dengan pelaksanaan. Hal tersebut penting untuk 
meminimalisir terjadinya distorsi dalam pemanfaatan dana desa di Desa Jenggala.

Selain itu, pendamping desa (agen) juga memiliki peranan penting dalam melakukan evaluasi pemanfaatan dana desa. Pendamping desa yang notabenenya merupakan mitra strategis dari pemerintah memiliki kewajiban untuk memberikan masukan dan bimbingan kepada pemerintah desa untuk optimalisasi pemanfaatan dana desa. Oleh karena itu, agen-agen di level Pemerintah Desa Jenggala harus mampu mengidentifikasi permasalahan dalam pemanfaatan dana desa untuk kemudian dievaluasi.

Minimnya partisipasi masyarakat secara swadaya dan terbatasnya sisa anggaran setelah gempa telah menjadi bagian evaluasi penting dalam pemanfaatan dana desa di Desa Jenggala. Selain itu, adanya keterlambatan Perbub dan rekapitulasi data kerusakan pemukiman masyarakat setelah gempa juga telah berdampak terhadap lambatnya pencairan dana desa pada tahap III sehingga hal tersebut menyebabkan terhambatnya pelaksanaan program dana desa yang berfokus pada rehabilitasi dan rekonstruksi.

Oleh karena itu, untuk menyikapi setiap permasalahan dan tantangan dalam pemanfaatan dana desa tahun 2018 di Desa Jenggala, para agen di level pemerintahan desa kemudian melakukan sistem supervisi dan pendampingan dalam setiap proses tahapan pelaksanaan dana desa. Sistem supervisi atau pengawasan dilakukan oleh BPD sebagai upaya untuk memastikan bahwa tahap pelaksanaan dana desa di Desa Jenggala sesuai dengan yang sudah direncanakan.

\section{Pemanfaatan Dana Desa di Desa Jenggala Tahun 2018}

\section{a. Pemanfaatan Dana Desa Sebelum Gempa}

Desa Jenggala pada tahun 2018 mendapatkan alokasi dana desa sebesar Rp 1.518.535.500. Pemanfaatan dana desa di Desa Jenggala sebelum terjadinya gempa lebih difokuskan pada bidang pembangunan fisik sebesar 
80,76 persen dan untuk pemberdayaan masyarakat desa hanya dialokasikan sebesar 19,24 persen.

1) Bidang Pembangunan Fisik.

a. Sarana prasarana pembangunan dan pelestarian lingkungan desa;

b. Sarana prasarana jalan usaha tani;

c. Sarana prasarana kesehatan desa;

2) Bidang Pemberdayaan Masyarakat.

a. Dukungan insentif guru dan kader desa;

b. Sosialisasi terkait kesehatan masyarakat desa;

c. Dukungan permodalan BUMDES.

\section{b. Pemanfaatan Dana Desa Setelah Gempa Gempa}

Setelah gempa program pembangunan fisik hanya dialokasikan sebesar 37,72 persen dan lebih difokuskan pada aspek pemberdayaan masyarakat desa yang mencapai 62,28 persen.

1) Bidang Pembangunan Fisik.

a. Sarana dan prasarana pendidikan setelah gempa.

b. Pembangunan, penataan dan penyediaan sarana prasarana lingkungan hidup setelah gempa.

2) Bidang Pemberdayaan Masyarakat.

a. Bantuan stimulan huntara.

b. Penataan, pengadaan dan normalisasi lingkungan hidup setelah gempa.

3) Kritik Terhadap Konsep Program Pemberdayaan Masyarakat Setelah Gempa melalui dana desa di Desa Jenggala.

Secara konseptual, pemberdayaan masyarakat adalah memberikan sumber daya, kesempatan, pengetahuan, dan keterampilan kepada warga untuk meningkatkan kemampuan mereka dalam menentukan masa depannya sendiri dan berpartisipasi dalam dan mempengaruhi kehidupan dari masyarakatnya (Jim Ife dalam Zubaedi, 2013) 
Berdasarkan konsep di atas, program dana desa di Desa Jenggala yang khususnya untuk bidang pemberdayaan masyarakat setelah gempa bumi terkesan bersifat charity dan lebih tepat dikategorikan sebagai program pembangunan fisik. Artinya, program-program tersebut tidak merepresentasikan bahwa masyarakat diberdayakan. Namun, justru masyarakat hanya dijadikan sebagai objek dari program dan bukan sebagai subjek program pemberdayaan masyarakat. Hal tersebut dapat dilihat dari sifat program yang hanya bersifat stimulan dan temporer.

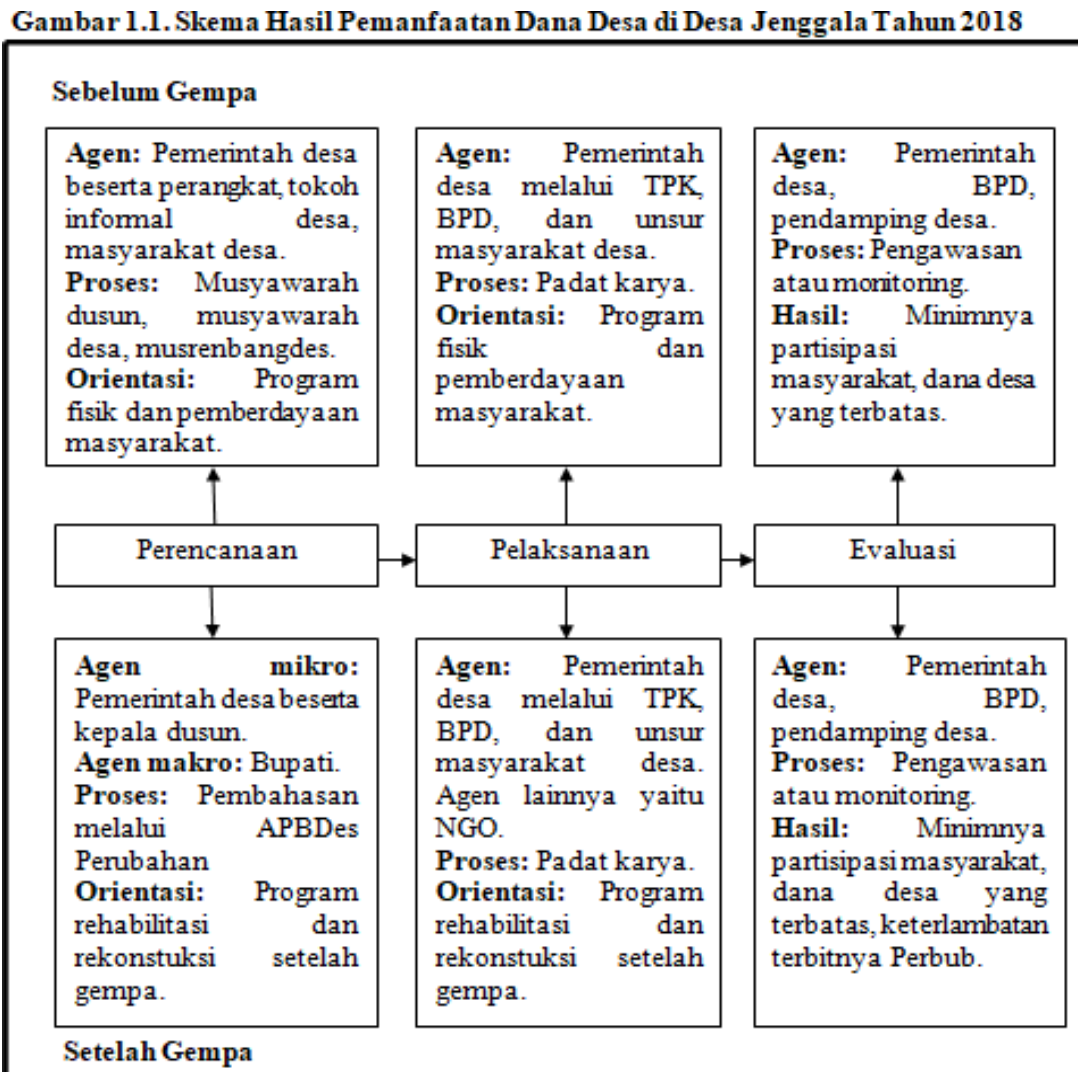

Sumber: diolaholeh peneliti, 2019

Oleh karena itu, Pemerintah Desa Jenggala belum secara optimal dalam memberikan limitasi antara konsep pembangunan fisik dan pemberdayaan masyarakat. Dampak dari persoalan tersebut kemudian adanya ketidaksesuaikan antara konsep program dengan jenis 
kegiatannya. Oleh sebab itu, meskipun setelah gempa bumi anggaran untuk bidang pemberdayaan masyarakat meningkat secara signifikan, namun secara koseptual jenis kegiatan yang dilakukan belum dapat dikatakan sebagai proses pemberdayaan

\section{Kesimpulan}

Berdasarkan temuan hasil penelitian tentang pemanfaatan dana desa tahun 2018 di Desa Jenggala, maka dapat dibuat kesimpulan sebagai berikut:

1. Pada tahap perencanaan dana desa sebelum dan setelah gempa bumi di Desa Jenggala dari aspek agen dan struktur, proses perencanaan program dan orientasi dari fokus perencanaan program telah mengalami perubahan.

2. Pada tahap pelaksanaan dana desa sebelum dan setelah gempa bumi di Desa Jenggala dalam aspek agen dan struktur serta fokus orientasi pelaksanaan program prioritas mengalami perubahan, sementara proses pelaksanaan tidak mengalami perubahan.

3. Pada tahap evaluasi pelaksanaan dana desa sebelum dan setelah gempa bumi di Desa Jenggala dalam aspek agen dan struktur, proses evaluasi program, dan hasil dari evaluasi program relatif sama atau tidak mengalami perubahan, hanya saja setelah gempa terjadi keterlambatan terbitnya Peraturan Bupati.

4. Desa Jenggala pada tahun 2018 mendapatkan alokasi dana desa sebesar Rp 1.518.535.500. Pemanfaatan dana desa di Desa Jenggala sebelum terjadinya gempa lebih difokuskan pada bidang pembangunan fisik sebesar 80,76 persen dan untuk pemberdayaan masyarakat desa hanya dialokasikan sebesar 19,24 persen. Namun, setelah gempa program pembangunan fisik hanya dialokasikan sebesar 37,72 persen dan lebih difokuskan pada aspek pemberdayaan masyarakat desa yang mencapai 62,28 persen. 


\section{Daftar Pustaka}

Badan Pengawasan Keuangan dan Pembangunan. Petunjuk Pelaksanaan Bimbingan dan Konsultasi Pengelolaan Keuangan Desa. 2015.

Basrowi dan Suwandi. 2008. Memahami Penelitian Kualitatif. Jakarta: PT. Rineka Cipta.

Damsar. 2015. Pengantar Teori Sosiologi. Jakarta: Prenadamedia Group.

Giddens, Anthony. 1984. Teori Strukturasi Dasar-Dasar Pembentukan Struktur Sosial Masyarakat. Terjemahan oleh Maufur dan Daryanto. 2010. Yogyakarta: Pustaka Pelajar.

Kementerian Desa, Pembangunan Daerah Tertinggal dan Transmigrasi RI. Pengembangan Desa. 2015.

Kementerian Keuangan RI. Buku Saku Dana Desa (Dana Desa Untuk Kesejahteraan Rakyat). 2017.

Palupi, Sri dkk. 2016. Buku Panduan Pelaksanaan Undang-Undang Desa Berbasis Hak. Jakarta: Lakpesdam PBNU.

Peraturan Bupati Kabupaten Lombok Utara Nomor 40 Tahun 218 tentang Prioritas Penggunaan Dana Desa untuk Rehabilitasi dan Rekonstruksi Masyarakat Setelah Gempa Bumi.

Peraturan Undang-Undang Nomor 6 tahun 2014 tentang Desa.

PP. Nomor 60 tahun 2014 tentang Dana Desa yang bersumber dari APBN. Pujileksono, Sugeng. 2016. Metode Penelitian Komunikasi Kualitatif. Malang:

Intrans Publishing.

Rahardjo. 2014. Pengantar Sosiologi Pedesaan dan Pertanian. Yogyakarta: Gadjah Mada University Press.

Ritzer, George. 2014. Teori Sosiologi Modern. Jakarta: Kencana.

Satori, Djam'an, Aan Komariah. 2014. Metodologi Penelitian Kualitatif. Bandung: Alfabeta.

Sugiyono. 2017. Metode Penelitian Kuantitatif, Kualitatif, dan R\&D. Bandung: Alfabeta.

Waskitojati, Damar, dkk. 2016. Model Proses Penganggaran Pembangunan Desa Secara Partisipatif. Jawa Tengah: Lembaga Percik Salatiga.

Website Resmi Badan Pusat Statistik (BPS), www.bps.go.id

Website Resmi Direktorat Jenderal Perimbangan Keuangan-Kementerian Keuangan (DJPK-Kemenkeu), www.djpk.kemenkeu.go.id

Wirawan, I. B. 2012. Teori-Teori Sosial dalam Tiga Paradigma. Jakarta: Prenadamedia Group.

Zubaedi. 2013. Pengembangan Masyarakat: Wacana dan Praktik. Jakarta: Kencana .Prenadamedia Group 